\title{
Teachers of Hospital Pedagogy: A Systematic Review
}

\author{
Lucas Ávalos ${ }^{1}$ \\ María Beatriz Fernández²
}

\begin{abstract}
Hospital teachers face the challenge of working in complex contexts with few empirical references. This systematic review aims to analyze empirical studies published between 2000-2020 related to teaching in hospital settings. Using the PRISMA guidelines, we identified 363 articles in the Web of Science, SciELO and Scopus databases: 11 studies were selected after the inclusion criteria were applied. We identified three areas of study: research trends; work dimensions and teacher characteristics; and challenges. We found a predominance of descriptive studies, theoretical frameworks of inclusion and civil rights, and female teachers and researchers. The analyzed studies emphasize emotional aspects, a lack of guidelines, and difficulties related to teachers' work. We conclude by signaling the need to strengthen the methodology of related studies, increase the joint responsibility of teachers and medical staff, and generate specific policies and preparation. These findings identify advances and challenges in the field that could guide its development.
\end{abstract}

Keywords: special education, school inclusion, teaching work

\section{Professores em Pedagogia Hospitalar: Uma Revisão Sistemática}

\begin{abstract}
Resumo: Professores hospitalares enfrentam o desafio de trabalhar em contextos complexos com poucos antecedentes empíricos. Esta revisão sistemática teve como objetivo analisar os estudos empíricos publicados entre 2000 e 2020 sobre a pedagogia em contextos hospitalares. Utilizando as diretrizes PRISMA, identificamos 363 artigos nas bases de dados: Web of Science, SciELO y Scopus, selecionamos 11 conforme o critério de inclusão. Identificamos três categorias: tendências de estudo; dimensões de trabalho e características docentes; e desafios. Os resultados mostram a predominância de estudos descritivos; estudos teóricos sobre inclusão e direitos; e mulheres como docentes e investigadoras. As investigações enfatizam aspectos emocionais, falta de orientação e dificuldades relacionais do trabalho docente. Concluímos que existe uma necessidade de fortalecer metodologicamente os estudos, aumentar a corresponsabilidade entre docente e equipe médica; e gerar politicas de formação específica. Esses achados identificam avanços e desafios no campo, podendo orientar o seu desenvolvimento.
\end{abstract}

Palavras-chave: educação especial, inclusão escolar, trabalho docente

\section{Docentes en Pedagogía Hospitalaria: Una Revisión Sistemática}

Resumen: Los/as docentes hospitalarios/as enfrentan el desafío de incluir en contextos complejos con pocos antecedentes empíricos. Esta revisión sistemática tuvo por objetivo analizar los estudios empíricos publicados entre el 2000-2020 sobre docencia en pedagogía hospitalaria. Utilizando los lineamientos PRISMA, identificamos 363 artículos en las bases de datos Web of Science, SciELO y Scopus, seleccionando 11 bajo criterios de inclusión. Identificamos tres categorías transversales: tendencias de estudio; dimensiones del trabajo y características docentes; y desafíos. Los resultados muestran el predominio en el campo de: estudios descriptivos; enfoques teóricos de inclusión y derecho; y mujeres como docentes e investigadoras. Las investigaciones enfatizan en aspectos emocionales, la falta de orientaciones y dificultades relacionales del trabajo docente. Se concluye la necesidad de fortalecer metodológicamente los estudios, aumentar la corresponsabilidad docente-personal médico; y generar políticas y formación específica. Estos hallazgos identifican avances y desafíos en el campo pudiendo orientar su desarrollo.

Palabras clave: educación especial, inclusión escolar, trabajo docente

${ }^{1}$ Universidad de Chile, Santiago de Chile, Chile

${ }^{2}$ CIAE e Instituto de Estudios Avanzados en Educación, Universidad de Chile, Santiago de Chile, Chile

Support from ANID/PIA/Basal Funds for Centers of Excellence FB0003 is gratefully acknowledged

Correspondence address: Lucas Ávalos. Universidad de Chile. Capitán Ignacio Carrera Pinto, 1045, Ñuñoa, Región Metropolitana, Santiago de Chile, Chile. CEP 1025000. E-mail: lucas.avalos@ug.uchile.cl
Hospital pedagogy (HP) emerged in the mid-twentieth century to avoid the exclusion of children and young people from the educational system by providing schooling in hospital contexts. This field of education has been a recent focus in the literature (Palomares-Ruiz, Sánchez-Navalón, \& Garrote-Rojas, 2016). The inclusion of the word "hospital" in HP has the core function of defining the pedagogical task and distinguishing HP as a specific field of pedagogy (Lizasoáin \& Polaino-Lorente, 1996). 
HP exists in almost all countries, and although it is implemented differently (Palomares-Ruiz et al., 2016), three modalities are recognized: bedside teaching, teaching in a classroom within or adjacent to the medical center, and home-based teaching (Fundación Carolina Labra Riquelme [FCLR], 2019). The student body served by teachers in HP is heterogeneous in terms of age, educational level, and medical pathology (Palomares-Ruiz et al., 2016); for example, hospital teachers may work with students in cancer treatment, those with physical or multiple disabilities, and those with mental health problems (FCLR, 2019). In this sense, hospital teachers face the challenge of providing inclusive education in a diverse and complex context (Riquelme, 2006; Souza \& Rolim, 2019). Some of the central problems faced by these teachers are the lack of training and an empirical background with which to develop their work (Riquelme, 2006). Although theoretical studies are numerous (Fernandéz Hawrylak, 2000; Latorre Medina \& Blanco Encomienda, 2010; Serradas Fonseca, 2015) and there are general guidelines for pedagogical work in each country (Palomares-Ruiz et al., 2016), the empirical literature on HP was comparatively undeveloped at the beginning of this century. In addition, to date, no academic article is available that synthesizes and analyzes the main empirical findings in this field and can guide teaching in these contexts based on scientific evidence.

Therefore, a systematic review of the empirical studies in this field is relevant to determine the main contributions, knowledge gaps, and challenges in the field and can guide future studies to deepen key aspects of its development. This study aims to analyze empirical studies published between 2000-2020 related to teaching in hospital settings. Specifically, the study seeks to (1) analyze the approaches and methodologies from which HP has been studied, (2) understand what aspects of HP have been studied, and (3) identify challenges and problems reported in relation to teachers in HP.

\section{Method}

The study was guided by a methodological proposal for a systematic review by Sánchez-Meca (2010) and by the PRISMA guidelines (identification, screening, eligibility and inclusion). Articles published in English and Spanish were identified between April and June 2020 in three databases: Web of Science, SciELO and Scopus. The search strategy in Spanish was aula hospitalaria OR pedagogía hospitalaria OR pedagogía domiciliaria OR pedagogía domicilio OR hospitalización AND docente OR profesor. The strategy in English was hospital classroom OR hospital class OR hospital pedagogy OR hospital school OR/AND teacher OR educator AND pediatric OR chronic illness.

For screening and determining the eligibility of the articles, the following inclusion criteria were established: (1) published in the last 20 years; (2) written in Spanish, English or Portuguese; (3) the central axis was the hospital teacher and/or his or her place within the study; (4) included the experience of teachers in terms of either learning processes; relationships with other actors, such as the health team and/or guardians; and/or the competencies required in this context. Originally, only articles published in the last 10 years were included. However, given the limited literature in the field, selection was extended to 20 years. The following articles were excluded: (1) those focusing on doctors who teach interns at hospitals and/or professionals in computer science, biochemistry, or nursing; (2) those focusing on relationships between regular schools and hospitals in which the teacher is not part of an HP program; (3) those focusing on the experiences of programs or workshops for hospitalized children that are not mediated by teachers; (4) those focusing on the performance of students in hospital classrooms without collecting information on teaching aspects; and (5) those focusing on the hospital classroom model and its impact without considering the teacher's perspective.

Of a total of 363 articles found in the three databases (Web of Science 95, Scopus 218 and SciELO 50), and 11 were selected based on the inclusion and exclusion criteria (inclusion process). This process is represented in Figure 1.

The 11 selected articles were coded in a matrix according to their objectives, research questions, research paradigms, methodologies, results, and conclusions. Then, crosssectional thematic categories were identified that addressed the differences and/or similarities of the studies. Table 1 summarizes the findings of the matrix.

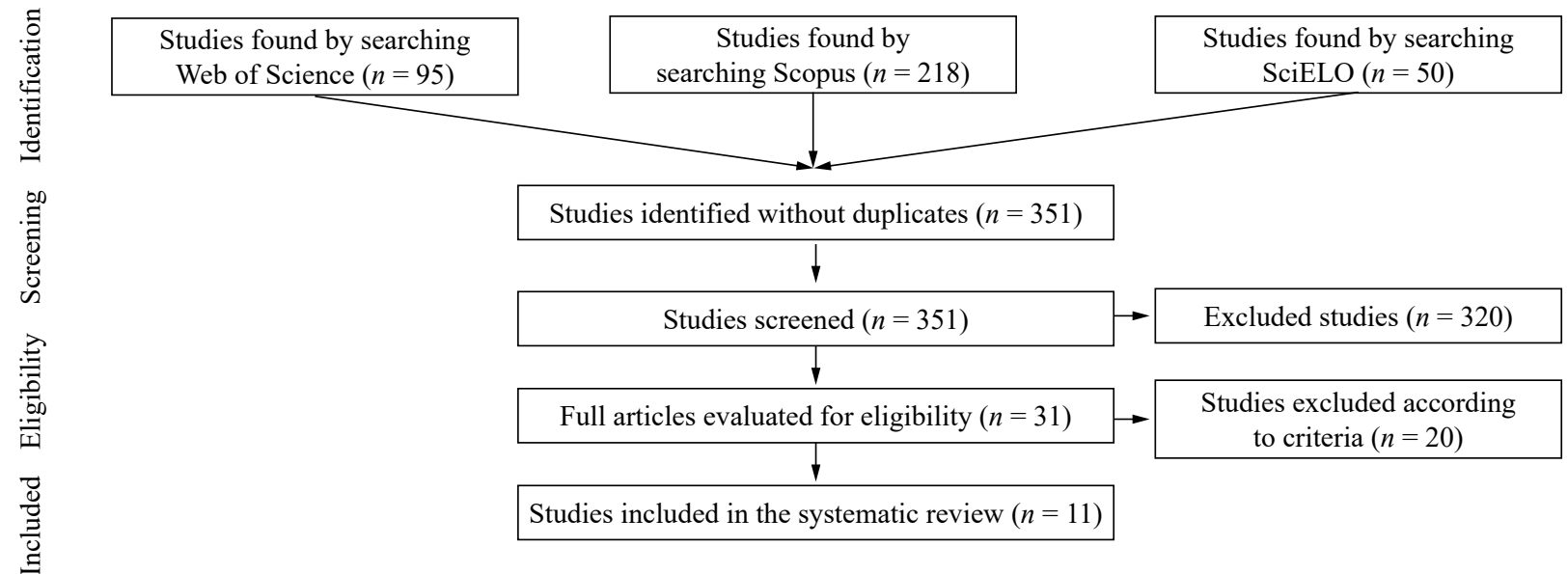

Figure 1. Article search and selection process. 
Table 1

Synthesis of the analyzed studies

Study perspective

Rights approach

(Ardón Esquivel et al., 2017; Bustos \& Cornejo, 2014; Crespo Molero \& Sánchez Romero, 2019; Ganem \& Silva, 2019; Gomes, Conceição, \& Cavalcante, 2019; Jiménez, Montes, \& Alcocer, 2019; Souza \& Rolim, 2019)

(Ardón Esquivel et al., 2017; Crespo Molero \& Sánchez Romero, 2019;

Inclusion approach Ganem \& Silva, 2019; Jiménez et al., 2019; Marchesan, Bock, Petrilli, Covic, \& Kanemoto, 2019;Souza \& Rolim, 2019)

Sociocultural approach

(Ardón Esquivel et al., 2017; Gomes et al., 2019; Marchesan et al., 2019; Souza \& Rolim, 2019)

Labor perspective

(Bustos \& Cornejo, 2014; Hen, 2018; Lozano Lima \& Genta Lugli, 2020)

Collaboration perspective

(Äärelä, Määttä, \& Uusiauttil, 2018)

Deterritorialization perspective

(Lozano Lima \& Genta Lugli, 2020)

Study methodology

Qualitative: (Äärelä et al., 2018; Ardón Esquivel et al., 2017; Bustos \& Cornejo, 2014;

Design

Ganem \& Silva, 2019; Gomes et al., 2019; Jiménez et al., 2019; Lozano Lima \& Genta Lugli, 2020; Marchesan et al., 2019; Souza \& Rolim, 2019)

Mixed: (Crespo Molero \& Sánchez Romero, 2019; Hen, 2018)

Interviews: (Ardón Esquivel et al., 2017; Ganem \& Silva, 2019; Gomes et al., 2019; Hen, 2018; Jiménez et al., 2019; Lozano Lima \& Genta Lugli, 2020; Marchesan et al., 2009;

Souza \& Rolim, 2019)

Data source

Questionnaires: (Crespo Molero \& Sánchez Romero, 2019)

Focus groups: (Bustos \& Cornejo, 2014)

Observation: (Äärelä et al., 2018; Ardón Esquivel et al., 2017; Gomes et al., 2019; Hen, 2018;

Jiménez et al., 2019)

Hospital teachers: (Äärelä et al., 2018; Ardón Esquivel et al., 2017; Bustos \& Cornejo, 2014; Crespo Molero \& Sánchez Romero, 2019; Ganem \& Silva, 2019; Gomes et al., 2019;

Hen, 2018; Souza \& Rolim, 2019)

Caregivers: (Jiménez et al., 2019)

Participants

Students: (Marchesan et al., 2009)

All participants are women: (Äärelä et al., 2018; Ardón Esquivel et al., 2017; Bustos \& Cornejo, 2014; Crespo Molero \& Sánchez Romero, 2019; Ganem \& Silva, 2019; Gomes et al., 2019; Hen, 2018; Jiménez et al., 2019; Lozano Lima \& Genta Lugli, 2020)

Content analysis: (Gomes et al., 2019; Hen, 2018)

Grounded theory: (Bustos \& Cornejo, 2014)

Type of analysis performed

Discourse analysis: (Ganem \& Silva, 2019)

Analytical methodology is not mentioned: (Äärelä et al., 2018; Ardón Esquivel et al., 2017;

Jiménez et al., 2019; Lozano Lima \& Genta Lugli, 2020; Marchesan et al., 2009)

\section{Results}

Three emerging categories were identified based on the similarities and differences of the studies: trends in the study of HP teaching, dimensions of the work and characteristics of the teacher, and challenges and problems.

\section{Trends in the Study of Teaching in Hospital Pedagogy}

The selected studies show clear trends in what aspects of HP teaching are studied and how. These trends can be analyzed separately as two subcategories.

\section{Theoretical Approaches in the Study of HP and the Teacher}

Two predominant theoretical approaches in the studies are recognized and justify the relevance of hospital pedagogy: rights and inclusion. In studies that use a rights approach, HP is conceived as necessary to safeguard and guarantee access to education for children and young people in cases of illness or hospitalization (Ardón Esquivel, Leytón Vega, Méndez Rodríguez, Monge Brenes, \& Valverde Cabezas, 2017; Bustos \& Cornejo, 2014; Crespo Molero \& Sánchez Romero, 2019; Ganem \& Silva, 2019; Gomes et al., 2019; 
Jiménez et al., 2019; Souza \& Rolim, 2019). These articles agree that the child or young person must be considered a subject of rights and expose the legal framework of the country or state where the study was conducted. In this sense, the authors also expose the rights of people with disabilities to equal opportunities in education (Ardón Esquivel et al., 2017; Ganem \& Silva, 2019).

The rights approach are not exclude the inclusion approach; in fact, many of the articles present complementary antecedents from both approaches to highlight HP's objective of providing education to children and young people in situations of illness or hospitalization (Ardón Esquivel et al., 2017; Crespo Molero \& Sánchez Romero, 2019; Ganem \& Silva, 2019; Jiménez et al., 2019; Souza \& Rolim, 2019). However, each approach has a different reading of this objective. The legal approach allows us to understand the student as a subject of rights. The inclusion approach involves ensuring that a child or young person who is ill can participate in society, including them as equals in education and recognizing their diversity (Ardón Esquivel et al., 2017; Crespo Molero \& Sánchez Romero, 2019; Ganem \& Silva, 2019; Jiménez et al., 2019; Souza \& Rolim, 2019). Studies that address HP teaching tend to be descriptive, using an inductive research approach. Related to the theoretical approaches used to understand teaching in $\mathrm{HP}$, the main focus of the studies is inclusion, followed to a lesser extent by perspectives on work and sociocultural approaches. Most of the articles that take the inclusion approach do so in terms of inclusive teaching practices (Ardón Esquivel et al., 2017; Crespo Molero \& Sánchez Romero, 2019; Ganem \& Silva, 2019; Jiménez et al., 2019; Marchesan. et al., 2009; Souza \& Rolim, 2019). However, only half of these articles clearly define this concept and refer to specific practices related to the diverse educational needs of students and the challenge of facilitating learning in the hospital context (Ardón Esquivel et al., 2017; Ganem. \& Silva, 2019; Marchesan et al., 2009). The rest note that inclusive teaching practices adhere to the guidelines of public policies in the related country without deeply developing this concept (Crespo Molero \& Sánchez Romero, 2019; Souza \& Rolim, 2019).

In contrast, Ganem and Silva (2019) and Jiménez et al. (2019) refer to teachers as a bridge for students between the world of the hospital and daily life, one that favors the inclusion of children and young people who are marginalized from society by their situation. This idea is also explored in statements that the teacher should generate a normalizing space for the child or young person (Crespo Molero \& Sánchez Romero, 2019). Although inclusion is a recurring theme, only one study focuses on the inclusive pedagogical practices of the teacher for promoting learning in this context (Ganem \& Silva, 2019).

A minority of studies, conducted in Brazil, use the sociocultural approach to study $\mathrm{PH}$, emphasizing the learning processes that guide hospital teachers (Gomes et al., 2019; Marchesan et al., 2009; Souza \& Rolim, 2019). Vygotsky is the main reference in discussion of the learning process and how it takes place, and Freire is the main reference when addressing the facilitation that teachers provide in this context. In contrast, Ardón Esquivel et al. (2017) present the sociocultural approach as part of the curriculum of a hospital classroom. To a lesser extent, the articles address hospital teaching from the perspective of work (Bustos \& Cornejo, 2014; Hen, 2018; Lozano Lima \& Genta Lugli, 2020). Among such articles, Hen (2018) takes a labor approach, with an emphasis on the production and effectiveness of the company or organization, addressing teaching procrastination in the administrative activities of a hospital school, while Bustos and Cornejo (2014) and Lozano Lima and Genta Lugli (2020) emphasize the particularities of teaching as a process of immaterial work that implies an affective dimension and is articulated around moral meanings and purposes. Finally, two specific approaches are recognized. First, Äärelä et al. (2018) analyze hospital teaching as a collaborative approach with the students' caregivers in terms of the distribution of responsibilities among actors and the ways in which collaboration occurs. Second, Lozano Lima and Genta Lugli (2020) examine teaching practice from the perspective of deterritorialization, a concept postulated by Deleuze and Guattari $(1992,2008)$ that refers to the teacher's departure from regular school to an unknown space and time: the hospital. Considering this review, it is necessary to develop conceptual clarifications related to HP to deepen the analysis of these experiences.

\section{Methodological Trends and Weaknesses}

All the articles are of a qualitative nature except for two that use mixed methods (Crespo Molero \& Sánchez Romero, 2019; Hen, 2018). Most use interviews - usually semistructured - as a data collection technique(Ardón Esquivel etal., 2017; Ganem \& Silva, 2019; Gomes et al., 2019; Hen, 2018; Lozano Lima \& Genta Lugli, 2020; Souza \&. Rolim, 2019), and only some use observations (Äärelä et al., 2018; Ardón Esquivel et al., 2017; Gomes et al., 2019; Hen, 2018). Although the studies were conducted mainly by teachers (Ardón Esquivel et al., 2017; Ganem \& Silva, 2019; Gomes et al., 2019; Lozano Lima \& Genta Lugli, 2020), only in Äärelä et al. (2018) one of the researchers was an HP teacher. The rest of the studies were developed by psychologists (Bustos \& Cornejo, 2014; Hen, 2018), nurses (Jiménez et al., 2019), and/or people who work in institutions related to the management of hospital classrooms (departments, educational institutions, or medical centers) (Crespo Molero \& Sánchez Romero, 2019; Souza \& Rolim, 2019). Most of the studies were conducted only by women (Ä̈relä et al., 2018; Ardón Esquivel et al., 2017; Ganem \& Silva, 2019; Hen, 2018; Lozano Lima \& Genta Lugli, 2020; Souza \& Rolim, 2019), while a smaller number were developed by peer teams with a predominance of women (Bustos \& Cornejo, 2014; Crespo Molero \& Sánchez Romero, 2019; Gomes et al., 2019; Jiménez et al., 2019); the exception is a study by a mixed team comprising a majority of men (Marchesan et al., 2009). 
Another trend is that most of the articles have hospital teachers as participants (Äärelä et al., 2018; Ardón Esquivel et al., 2017; Bustos \& Cornejo, 2014; Crespo Molero \& Sánchez Romero, 2019; Ganem \&. Silva, 2019; Gomes et al., 2019; Hen, 2018; Souza \& Rolim, 2019); the two exceptions have caregivers (Jiménez et al., 2019) and students (Marchesan et al., 2009) as participants responding to the role of the teacher at the hospital. It is common for samples to be small (between one and eight participants) (Äärelä et al., 2018; Bustos \& Cornejo, 2014; Crespo Molero \& Sánchez Romero, 2019; Ganem \& Silva, 2019; Gomes et al., 2019; Souza. \& Rolim, 2019). This is representative of HP because in general, one to three teachers work in each hospital classroom, and in the home care modality teachers work one on one with the student. The use of small samples can also be understood in terms of the qualitative nature of most of the studies, which seek to understand and deepen knowledge regarding hospital teaching in situated contexts.

It is noteworthy that all of teachers who participate in the studies are women. Some articles explain this finding in the methodology (Äärelä et al., 2018; Bustos \& Cornejo, 2014; Ganem \& Silva, 2019; Gomes et al., 2019; Hen, 2018), while others imply it in their reporting of the results (Ardón Esquivel et al., 2017; Lozano Lima \& Genta Lugli, 2020). In one study, the presence of female teachers is mentioned, but it is not made explicit, nor can it be inferred that all the teachers in the study are women (Crespo Molero \& Sánchez Romero, 2019). In addition, when students' caregivers are interviewed, the entire sample comprises female caregivers (Jiménez et al., 2019). This shows a clear gender trend in those who take responsibility for and carry out the tasks of caring for children and young people in situations of illness.

Additionally, half of the articles perform content analysis; however, only two articles clearly report that they are using this method (Gomes et al., 2019; Hen, 2018). In two studies, this is inferred by the way in which the results are presented (Lozano Lima \& Genta Lugli, 2020; Marchesan et al., 2009). Another study indicates the use of discourse analysis; however, the presentation of the results is consistent with the use of content analysis (Ganem \& Silva, 2019). There are contradictions between the proposed methodology and the methodology used when presenting the results. In one case, the qualitative nature of the article is mentioned, but quantitative analysis techniques are also used, and it can be inferred that the methodology is of a mixed nature (Hen, 2018). Another of the methodological weaknesses of the articles is linked to the scarce use of excerpts from the material that was produced to support the authors' claims (Äärelä et al., 2018; Marchesan et al., 2009) and the failure to provide the number of interviews that were conducted (Lozano Lima \& Genta Lugli, 2020). This obscures the process of the authors' data interpretation. Additionally, problems with coherence or argumentative consistency, discrepancies between the title and the results, differences between sections in the topics addressed (Souza \& Rolim, 2019), presenting results and conclusions in the background section (Crespo Molero \& Sánchez Romero, 2019), or presenting new concepts and topics in the conclusions or final sections are observed (Jiménez et al., 2019). These problems make it difficult to identify the central argument of these articles.

\section{Dimensions of the Work and Characteristics of the Teacher}

Studies on teaching in HP focus mainly on exposing and/or analyzing the multiple dimensions of the work, functions, and tasks of teachers in this context and describing their characteristics and competencies, both personal and professional. Although such information is not explicitly mentioned in all the articles, it can be inferred that teachers work in different modalities such as in the classroom (Äärelä et al., 2018; Ardón Esquivel et al., 2017; Bustos \& Cornejo; 2014; Crespo. Molero \& Sánchez Romero, 2019; Gomes et al., 2019; Hen, 2018; Jiménez et al., 2019; Lozano Lima \& Genta Lugli, 2020; Marchesan et al., 2009; Souza \& Rolim, 2019), at bedsides (Bustos \& Cornejo; 2014; Gomes et al., 2019; Hen, 2018), and in the student's homes (Ganem \& Silva, 2019).

The articles recognize characteristics attributed to hospital teachers by students, students' caregivers, and teachers themselves. The fundamental role of emotions is described (in three aspects): as a professional competence, as an experience associated with work, and in the relationship with students and their families. Teachers are expected to be able to manage times of emotional instability in students (Crespo Molero \& Sánchez Romero, 2019; Ganem \& Silva, 2019) and respond to students' and their families' needs for psychosocial support. In addition, teachers signify their work by the strong, intense, oscillating and extreme emotions they experience (Bustos \& Cornejo, 2014; Hen, 2018) and report feeling proud of and committed to their work (Ganem \& Silva, 2019). The studies note that the vocation is fundamental to face the emotional intensity and adverse educational context of the hospital (Ardón Esquivel et al., 2017). In addition, emotional aspects mark the relationships that teachers establish with students and their families; they establish close and trusting bonds (Bustos \& Cornejo, 2014), which sometimes implies conflicting knots in the bond with the students' caregivers (Äärelä et al., 2018). This bond with teachers is recognized and attributed to HP by teachers (Bustos \& Cornejo, 2014; Gomes et al., 2019; Souza \& Rolim, 2019), students (Marchesan et al., 2009), and students' caregivers (Jiménez et al., 2019).

The main teaching functions and tasks identified in the articles across HP modalities are the heterogeneity of the students (in terms of age, education level and health condition), and the differences among countries, as presented in Figure 2. 


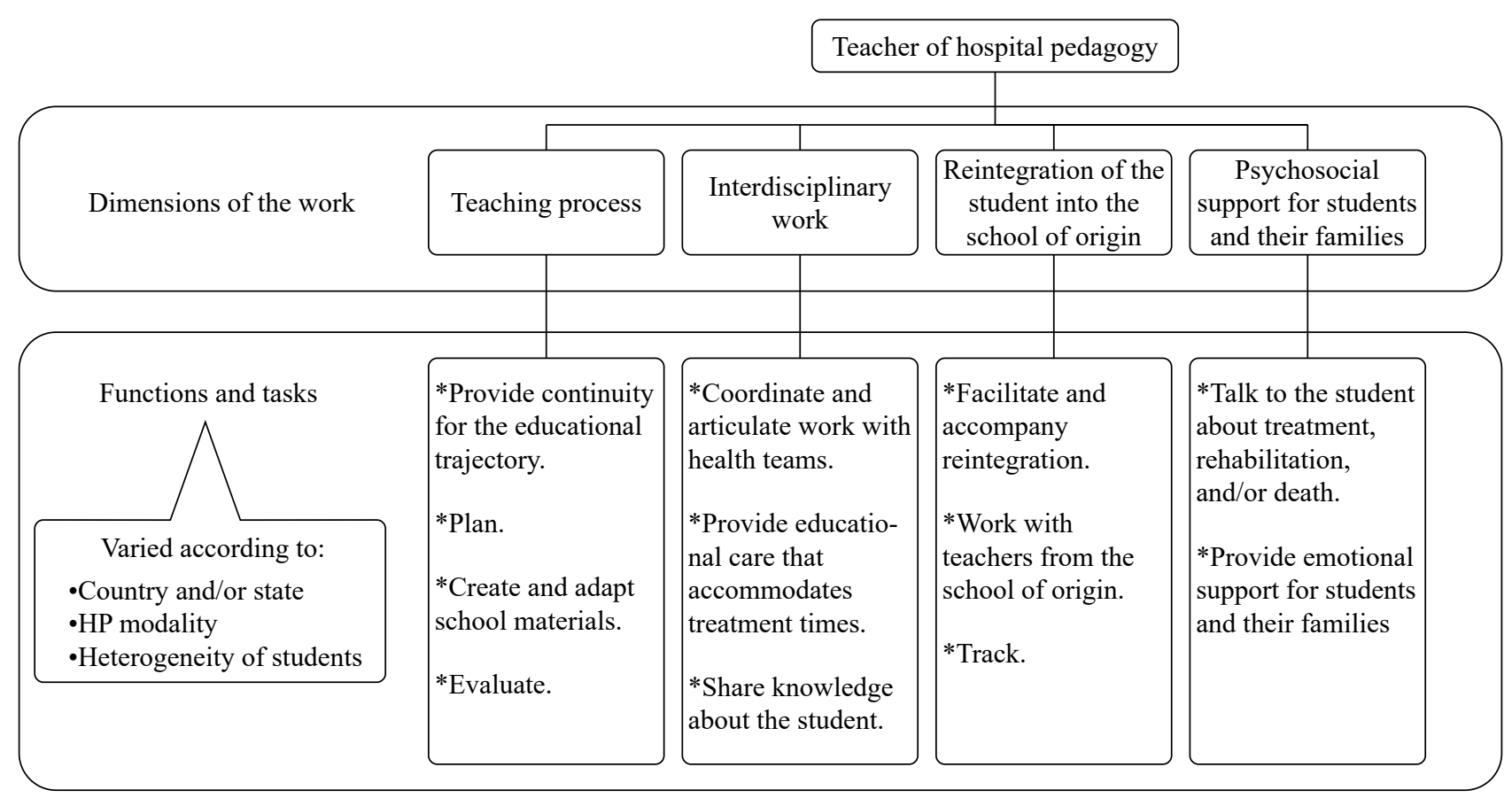

Figure 2. Teacher, dimensions of work, functions and tasks.

Regarding the teaching functions related to the teaching process dimension, the lesson is the main device used to facilitate the educational act. Lessons have particular characteristics: they are dynamic, changing and of short duration depending on the student's health and psychological and emotional condition of the student (Gomes et al., 2019; Lozano Lima \& Genta Lugli, 2020). The main task of this dimension is the adaptation of curricula, including the content, activities, material, and evaluations, to the student's situation (Äärelä et al., 2018; Ardón Esquivel et al., 2017; Bustos \& Cornejo; 2014; Crespo Molero \& Sánchez Romero, 2019; Ganem \& Silva, 2019; Gomes et al., 2019; Hen, 2018; Jiménez et al., 2019; Lozano Lima \& Genta Lugli, 2020; Marchesan et al., 2009; Souza \& Rolim, 2019). A factor that is relevant to teaching performance in this context is the available spaces and resources. When working at the student's bedside in the hospital, teachers should plan personalized lessons for each student and prepare the material in a way that is appropriate to that space (Gomes et al., 2019). When working in a classroom, the teacher has access to more didactic materials (Souza \& Rolim, 2019), and they teach multigrade classes (Äärelä et al., 2018; Ardón Esquivel et al., 2017; Bustos \& Cornejo; 2014; Crespo Molero \& Sánchez Romero, 2019; Gomes et al., 2019; Hen, 2018; Jiménez et al., 2019; Lozano Lima \& Genta Lugli, 2020; Marchesan et al., 2009; Souza \& Rolim, 2019). When working at the student's home, the resources, and spaces that the teacher uses depend on the family's resources (Ganem \& Silva, 2019).

Regarding school material, teachers must do more than adapt it; they must develop their own material - preferably playfully - for each lesson according to the student's health condition and the available resources and spaces (Crespo Molero \& Sánchez Romero, 2019; Gomes et al., 2019; Souza \& Rolim, 2019). These tasks explain why flexibility at work is a characteristic that is generally attributed to hospital teachers (Ardón Esquivel et al., 2017; Bustos \& Cornejo, 2014; Gomes et al., 2019; Lozano Lima \& Genta Lugli., 2019; Souza \& Rolim, 2019). It also explains a professional competence that contributes to the profile of the hospital teacher: attention to the diverse needs of each student (Äärelä et al., 2018; Ardón Esquivel et al., 2017; Ganem. \& Silva, 2019; Gomes et al., 2019; Hen, 2018; Jiménez et al., 2019; Lozano Lima \& Genta Lugli, 2019). Furthermore, specific tasks are recognized when teaching oncology students/patients, for whom teachers plan and execute lessons and perform evaluations during their time with the student, avoiding postponement and long-term planning (Lozano Lima \& Genta Lugli, 2019); in effect, the work takes place in the present (Bustos \& Cornejo, 2014). When a student enters the hospital classroom, the hospital teacher contacts the student's teacher at the school of origin to learn the student's curriculum so that the hospital teacher can continue the student's educational trajectory (without detriment) (Äärelä et al., 2018; Gomes. et al., 2019). This communication between teachers takes place through reports, with the guardians as intermediaries (Äärelä et al., 2018), or through conversations between teachers by telephone or digital channels (Gomes et al., 2019). In addition, at this stage, caregivers participate in the search for pedagogical solutions for their child's behavior and learning (Äärelä et al., 2018). This is one explanation for the intimate and close relationship between teachers and guardians (Bustos \& Cornejo, 2014). The second dimension 
of hospital teaching entails coordinating interdisciplinary and articulated work with health teams to provide comprehensive care for the child or young person receiving medical treatment. These articles expose interdisciplinary work as a key orientation in HP, where responsibility for this care is placed on the teacher (Äärelä et al., 2018; Ardón Esquivel et al., 2017; Crespo Molero \& Sánchez Romero, 2019; Ganem \& Silva, 2019; Gomes et al., 2019; Hen, 2018; Jiménez et al., 2019; Lozano Lima \& Genta Lugli, 2020; Marchesan et al., 2009; Souza \& Rolim, 2019). Hospital teachers must adapt their educational care to accommodate medical treatments (Lozano Lima \& Genta Lugli, 2020) and share their knowledge of the student to plan and execute lessons according to the student's health condition (Äärelä et al., 2018; Ganem \& Silva, 2019).

Regarding the third dimension, accompanying the reintegration of the student into his or her school of origin, hospital teachers establish communication with the teachers at the school when students' health allows them to reintegrate. The selected articles address working with the teacher at the school of origin to a lesser extent than other issues (Äärelä et al., 2018; Ardón Esquivel et al., 2017; Gomes et al., 2019). In the case of home-based HP, many students do not start their schooling in a regular establishment, and therefore, schoolteachers generally do not work in this area (Ganem \& Silva, 2019). Accompaniment takes placesin different ways: by sending reports through guardians (Äärelä et al., 2018; Ardón Esquivel et al., 2017) or direct contact through email or telephone (Gomes et al., 2019). In other cases, the hospital teacher not only provides information but also closely follows the student by visiting him or her at the school of origin and having face-to-face meetings with his or her teachers (Ardón Esquivel et al., 2017). Bustos and Cornejo (2014) state that teachers support students during reintegration, but the authors do not specify the associated tasks. Finally, the psychosocial support that teachers provide to students and their families in rehabilitation is a key factor in the adverse and painful context in which HP takes place. Teachers provide fundamental support for students and their families. This is reflected when teachers explain the treatment process to their students, are understanding about the pain and/or discouragement that chemotherapy can cause or talk about death with their students (Äärelä et al., 2018; Bustos \&. Cornejo, 2014; Gomes et al., 2019; Jiménez et al. 2019; Marchesan et al., 2009). Additionally, the treatment and the disease itself are often difficult and distressing situations for the caregivers of the child or young person. Therefore, teachers tend to emotionally support the family during this process (Äärelä et al., 2018; Bustos \& Cornejo, 2014; Jiménez et al., 2019).

\section{Challenges and Problems}

Although only Äärelä et al. (2018) and Ganem and Silva (2019) directly address hospital teachers' challenges and problems, these issues are present in all of the studies, particularly in two areas: teacher relations and structural conditions (public policies and teacher training).

\section{Teacher Relations}

The articles recognize that hospital teachers have a broad relational scope that includes links with students, other teachers, medical teams, students' caregivers (Äärelä et al., 2018; Ardón Esquivel et al., 2017; Bustos \&. Cornejo, 2014; Crespo Molero \& Sánchez Romero, 2019; Ganem \& Silva, 2019; Gomes et al., 2019; Jiménez et al., 2019; Lozano Lima \& Genta Lugli, 2020; Marchesan et al., 2009; Souza \& Rolim., 2019), and in some cases, the teachers at the students' school of origin (Äärelä et al., 2018; Ardón Esquivel et al., 2017; Gomes et al., 2019; Marchesan et al., 2009). Studies propose that teachers should adopt a collaborative relationship style for working with the hospital school community (Ganem \& Silva, 2019; Hen, 2018; Lozano Lima \& Genta Lugli, 2020). However, only Äärelä et al. (2018) address in depth the challenges and conflicts with caregivers and the teachers at the school of origin that emerge in this area. In this article, collaboration is part of the theoretical focus of analysis and not simply one of the antecedents or results that teachers report (Bustos \& Cornejo, 2014; Ganem \& Silva, 2019; Hen, 2018; Jiménez et al., 2019; Lozano Lima \& Genta Lugli, 2020). Regarding the relationship with the students, close and emotional ties are described. Nonetheless, behavioral conflicts are reported with or among students due to decompensation, and they may end with expulsion when teachers cannot handle the situation (Crespo Molero \& Sánchez Romero, 2019).

Regarding the relationship between hospital teachers and medical staff, some articles mention the relevance of interdisciplinary work with health teams for providing comprehensive care and its benefits for the student's recovery (Ganem \& Silva, 2019; Gomes et al., 2019; Lozano Lima \& Genta Lugli, 2020). In practice, interdisciplinary work is usually very difficult for teachers, who describe how health teams interrupt the development of lessons or hinder educational activities (Ganem \& Silva, 2019; Jiménez et al., 2019). In some cases, teachers perceive that medical treatment is prioritized over education (Hen, 2018; Jiménez et al., 2019). Only one study interviews nurses from the medical team who work with teachers, with the aim of comprehensively understanding hospital schools (Lozano Lima \& Genta Lugli, 2020). In this situation, one nurse expresses her desire to be part of the educational work; however, she tends to interrupt lessons and notes feeling uncomfortable in these situations (Lozano Lima \& Genta Lugli, 2020). Regarding the relationship between teachers and students' caregivers, challenges are associated with the emotional intensity of this relationship. On some occasions, hospital teachers perceive these challenges as very difficult and ambiguous, mainly due to the lack of tools with which to face the multiple emotional needs of students and their 
caregivers; this difficulty can cause burnout and stress, among other psychic ailments (Hen, 2018). In addition, conflicts often emerge when involving caregivers in the administrative work associated with pedagogical aspects because due to the emotional overload of their child's situation, caregivers often minimize the importance of completing reports and/or sending them to the student's school of origin (Äärelä et al., 2018; Gomes et al., 2019; Jiménez et al., 2019) or are uninterested in their child's schooling (Äärelä et al., 2018). Finally, regarding the relationship with the school of origin and its teachers, the main source of tension is the low participation of regular schoolteachers. It is inferred in the articles that the hospital teacher is responsible for carrying out detailed work with students, which reinforces the low responsibility of the teachers at the school of origin in the reintegration process (Äärelä et al., 2018; Crespo Molero \& Sánchez Romero, 2019; Ganem \& Silva, 2019; Gomes et al., 2019; Jiménez et al., 2019).

\section{Structural Conditions}

The articles denounce the absence of policies on HP in countries such as Brazil, Israel and Colombia. Mainly, deficiencies are identified along two axes: (1) Policies that consider the particularity of hospital classrooms. When they are governed by laws that apply to regular schools, hospital teachers must complete reports and records that are not relevant to the context in which they teach (Hen, 2018; Jiménez et al., 2019; Lozano Lima \& Genta Lugli, 2020). This generates overload and overwhelms the teachers, causing them to lose the meaning of schooling to administrative work (Hen, 2018); (2) Insufficient supply of HP teachers in these countries, which marginalizes students in situations of illness from the educational system (Gomes et al., 2019; Hen, 2018; Jiménez et al., 2019; Lozano Lima \& Genta Lugli, 2020).

Regarding teacher training, studies performed in Costa Rica, Spain, and Brazil expose the lack of initial or continuing training for hospital teachers (Ardón Esquivel et al., 2017; Crespo Molero \& Sánchez Romero, 2019; Gomes et al., 2019; Lozano Lima \& Genta Lugli, 2020). Studies criticize that training is focused on regular classrooms and mention the need for training on HP that incorporates the experiences of teachers in this area (Ardón Esquivel et al., 2017; Lozano Lima \& Genta Lugli, 2020). Additionally, due to the difficulty of the associated pedagogical work, the need for training to work with students with severe mental disorders is mentioned (Crespo Molero \& Sánchez Romero, 2019). Teacher training related to the affective field is also proposed due to the intense interactions that teachers experience when encountering the diseases and frailties of their students (Gomes et al., 2019).

In this sense, teachers report in their studies that they do not feel prepared to implement inclusive educational practices in the hospital (Crespo Molero \& Sánchez Romero, 2019; Lozano Lima \& Genta Lugli, 2020). Because of this, they often feel depressed and incompetent to teach children with complicated medical conditions (Hen, 2018). Many hospital teachers abandon this work because they are not prepared to deal with such a heterogeneous student population (Gomes et al., 2019). Appropriate teacher training policies and instances could strengthen HP, providing support in a difficult work context (Bustos \& Cornejo, 2014; Hen, 2018).

\section{Discussion}

As in the case of theoretical studies in the field of HP (Fernandéz Hawrylak, 2000; Latorre Medina \& Blanco Encomienda, 2010; Serradas Fonseca, 2015), the main areas of empirical study are the functions and tasks of teachers and their personal and/or professional characteristics. In addition, empirical studies are based on rights and inclusion approaches and predominantly understand the phenomenon of HP from the perspective of inclusive pedagogical practices. Research in the area arises, for the most part, from an interpretive paradigm using qualitative methodologies. The studies identify that the main problems that hospital teachers face arise from relationships with health teams and caregivers at work and the lack of teacher training and specific policies for this modality of teaching.

From the analyzed studies, five aspects of the field of HP teaching are identified. First, empirical studies tend to focus on the description of the functions and tasks of HP teachers, delving into the particularities of their work in each context. This emphasis is relevant given the high heterogeneity of practices in the profession (Palomares-Ruiz et al., 2016). However, this contextual and descriptive focus makes it difficult to conduct a deeper analysis of the results in relation to the conceptual frameworks used. For example, it is common to use the inclusion and rights approaches to support the position of HP in the educational field or its relevance in educational policy, but studies rarely use these approaches to interpret the information they obtain. It is necessary to advance the diversification and depth of theoretical development in the field, maintaining attention to the context but surpassing the descriptive emphasis. Second, methodological weaknesses are observed (e.g., limited descriptions of the information analysis techniques and analyzed material), which puts the validity of the proposed interpretations at risk (Maxwell, 1992). These weaknesses could be explained by the incipient nature of the field of HP research, which is evident in the low number of empirical articles in the field that have been published in the last 20 years.

Third, it is relevant to problematize the high proportion of women in the field of HP. This trend can be understood when HP is analyzed from the perspective of care work. $\mathrm{HP}$ is directly related to tasks involved in the maintenance or preservation of life, which are most often performed by women because women have traditionally been assigned these tasks through cultural expectations that affect behaviors and attitudes (Arango \& Molinier, 2011; Lorente Molina, 2004). It is relevant to develop studies with feminist theoretical perspectives that understand HP teaching as historically feminized work and not as a female role. 
Fourth, collaboration is noted as a central concept in HP; however, it is pointed out as an orientation for teachers in their work with health teams and guardians. Only Äärelä et al. (2018) propose collaboration as a bidirectional perspective and as a response to conflict among actors. In this sense, it is necessary to establish shared responsibility with health teams and teachers at the student's school of origin to institutionally define times and workspaces. This could favor the reduction of conflicts and improve hospital teachers' well-being in a context characterized by overload and frequent reports of burnout syndrome (Hen, 2018). This is also relevant in a context marked by heavy demands and emotional intensity, which teachers, students, and caregivers alike describe as a fundamental part of the work. Therefore, it is important to develop studies on emotional aspects and occupational health in hospital teaching. Finally, studies show the lack of policies and adequate teacher training in a context with high levels of work burden due to adverse working conditions (Hen, 2018). It is urgent to advance the creation of educational policies and specific teacher training programs for HP and to take actions that protect hospital teachers' occupational health in an emotionally intense context (Bustos \& Cornejo, 2014; Hen, 2018).

This study presents the main findings regarding HP, which can guide the work of teachers and decision-makers in the area. Furthermore, it identifies the main theoretical and methodological challenges in the field, which is relevant information for future research to strengthen the development of the field.This review, however, is limited to studies published in the Anglo- and IberoAmerican contexts, making it necessary for other studies to deepen the scientific production of other regions.

\section{References}

Äärelä, T., Määttä, K., \& Uusiautti, S. (2018). The challenges of parent-teacher collaboration in the light of hospital school pedagogy. Early Child Development and Care, 188(6), 709-722. doi:10.1080/03004430.2016.1230108

Arango, L. G., \& Molinier, P. (2011). El trabajo y la ética del cuidado [Work and the ethics of care]. Medellín, Colombia: La Carreta Social y Escuela de Estudios de Género, Universidad Nacional de Colombia.

Ardón Esquivel, D., Leytón Vega, F., Méndez Rodríguez, N., Monge Brenes, K., \& Valverde Cabezas, G. (2017). La pedagogía hospitalaria en Costa Rica: La atención a la niñez menor de siete años de edad [Hospital pedagogy in Costa Rica: Attention to children under seven years of age]. Actualidades Investigativas en Educación, 17(1), 1-23. doi:10.15517/aie.v17i1.27295
Bustos, C., \& Cornejo, R. (2014). Sentidos del trabajo en docentes de aulas hospitalarias: Las emociones y el presente como pilares del proceso de trabajo [Senses of work in hospital classroom teachers: Emotions and the present as pillars of the work process]. Psicoperspectivas Individuo y Sociedad, 13(2), 186-197. doi:10.5027/psicoperspectivas-Vol13-Issue2-fulltext-365

Crespo Molero, F., \& Sánchez Romero, C. (2019). Alumnado con trastorno mental grave: Análisis de la atención educativa recibida en la Comunidad de Madrid [Students with severe mental disorders: Analysis of the educational attention received in the Community of Madrid]. Psychology, Society, \& Education, 11(1), 113-124. doi:10.25115/psye.v10i1.2124

Deleuze, G., \& Guattari, F. (1992). O que é a filosofia? [What is philosophy?] (B. Prado Jr. \& A. A. Muñoz, Trans.). Rio de Janeiro, RJ: Editora 34.

Deleuze, G., \& Guattari, F. (2008). Mil-Platôs: Vol. 1. Capitalismo e esquizofrenia [Thousand Plateaus: Vol. 1. Capitalism and schizophrenia] (A. L. Oliveira, A. Guerra Neto, \& C. P. Costa, Trans.). Rio de Janeiro, RJ: Editora 34.

Fernandéz Hawrylak, M. (2000). La pedagogía hospitalaria y el pedagogo hospitalario [Hospital pedagogy and the hospital teacher]. Tabanque, (15), 139-150. Retrieved from https://uvadoc.uva.es/bitstream/handle/10324/8826/ Tabanque-2005-15-LaPedagogiaHospitalariaYEIPedago goHospitalario.pdf? sequence $=1 \&$ is Allowed $=\mathrm{y}$

Fundación Carolina Labra Riquelme. (2019). Dos décadas de experiencia en pedagogía hospitalaria [Two decades of experience in Hospital Pedagogy]. Santiago, Chile: Santillana. Retrieved from https://www.fclr.cl/wp-content/uploads/2020/08/ DOS_DECADAS_PEDAG_HOSPT-min.pdf

Ganem, L. S., \& Silva, C. C. B. (2019). Pedagogical home care actions: Possibilities and challenges. Revista Brasileira de Educação Especial, 25(4), 587-602. doi:10.1590/s1413-65382519000400004

Gomes, R. B. G., Conceição, C. C., \& Cavalcante, T. C. F. (2019). A importância da classe hospitalar Semear do Recife no processo de continuidade da escolarização dos estudantes/ pacientes com câncer [The importance of the hospital school program Semear do Recife in the process to continue the schooling of students/patients with cancer]. Revista Brasileira de Estudos Pedagógicos, 100(256), 633-650. doi:10.24109/2176-6681.rbep.100i256.4068

Hen, M. (2018). Causes for procrastination in a unique educational workplace. Journal of Prevention \& Intervention in the Community, 46(3), 215-227. doi:10.1080/10852352.2018.1470144 
Jiménez, N. N. V., Montes, J. E. O., \& Alcocer, E. C. P. (2019). Hospital pedagogy: A space of love and recognition for the oncological pediatric patient. Texto \& Contexto - Enfermagem, 28, e20180112. doi:10.1590/1980-265X-TCE-2018-0112

Latorre Medina, M. J., \& Blanco Encomienda, F. J. (2010). Función profesional del pedagogo en centros hospitalarios como ámbitos educativos excepcionales [Professional role of the pedagogue in hospitals as exceptional educational settings]. Educación XX1, 13(2), 95-116. doi:10.5944/educxx1.13.2.239

Lizasoáin Rumeu, O., \& Polaino-Lorente, A. (1996). La pedagogía hospitalaria como un concepto unívoco e innovador [Hospital pedagogy like a unique and innovative concept]. Comunidad Educativa, (231), 14-15.

Lorente Molina, B. (2004). Género, ciencia y trabajo. Las profesiones feminizadas y las prácticas de cuidado y ayuda social [Gender, science and work. Feminized professions and social care and support practices]. Scripta Ethnologica, (26), 39-53. Retrieved from https://www.redalyc.org/pdf/148/14802602.pdf

Lozano Lima, A. M., \& Genta Lugli, R. S. (2020). Os tempos da ação docente na classe hospitalar [The times of teaching action in the hospital class]. Educação, 45, 1-19. doi: $10.5902 / 1984644440241$

Marchesan, E. C., Bock, A. M. B., Petrilli, A. S., Covic, A. N., \& Kanemoto, E. (2009). A não-escola: Os sentidos atribuídos à escola e ao professor hospitalares por pacientes oncológicos [The non-school: The meanings attributed to hospital school and teacher by cancer patients]. Psicologia: Ciência e Profissão, 29(3), 476-493. doi:10.1590/S1414-98932009000300005

Maxwell, J. (1992). Understanding and validity in qualitative. Harvard Educational Review, 62(3), 279-300. doi:10.17763/haer.62.3.8323320856251826

Palomares-Ruiz, A., Sánchez-Navalón, B., \& GarroteRojas, D. (2016). Educación inclusiva en contextos inéditos: La implementación de la Pedagogía Hospitalaria [Inclusive education in unprecedented contexts: The implementation of Hospital Pedagogy]. Revista Latinoamericana de Ciencias Sociales, Niñez y Juventud, 14(2), 1507-1522. Retrieved from http://www.scielo.org.co/pdf/rlcs/v14n2/v14n2a43.pdf

Riquelme, S. (2006). Aulas y pedagogía hospitalaria en Chile. Santiago, Chile: Grafimpres.

Sánchez-Meca, J. (2010). Cómo realizar una revisión sistemática y un meta-análisis [How to conduct a systematic review and meta-analysis]. Aula Abierta, 38(2), 53-64.

Serradas Fonseca, M. (2015). La pluridimensionalidad del rol del docente hospitalario.Educ@ción en Contexto, 1(2), 38-55. Retrieved from https://educacionencontexto. net/journal/index.php/una/article/view/17/24
Souza, Z., \& Rolim, C. (2019). As vozes das professoras na pedagogia hospitalar: Descortinando possibilidades e enfrentamentos [The voices of the teachers in the hospital pedagogy: Unveiling possibilities and confrontations]. Revista Brasileira de Educação Especial, 25(3), 403-420. doi:10.1590/s1413-65382519000300004

Lucas Avalos is master's candidate at the Facultad de Ciencias Sociales, Universidad de Chile, Santiago de Chile, Chile.

María Beatriz Fernández is an assistant professor of CIAE, Instituto de Estudios Avanzados en Educación, Universidad de Chile, Santiago de Chile, Chile.

\section{Authors' Contribution:}

All of the authors made substantial contributions to the conception and design of this study, the data analysis and interpretation, and the revision of the manuscript and approved the final version. All of the authors assume public responsibility for the content of the manuscript.

Associate Editor:

Fábio Scorsolini-Comin

Received: Jun. 17, 2021

1st Revision: Jul. 28, 2021

Approved: Aug. 27, 2021
How to cite this article:

Ávalos, L., \& Fernández, M.B. (2021). Teachers in hospital pedagogy: A systematic review. Paidéia (Ribeirão Preto), 31, e3139. doi: https://doi.org/10.1590/1982-4327e3139 